\title{
WILD LIFE IN SOUTHERN ETHIOPIA
}

\author{
By Captain D. S. Sorrell
}

During 1950 and early 1951 I was fortunate enough to be able to study and observe the state of wild life in South Ethiopia, a privilege that few Europeans can claim in recent years. The area concerned lies north of the Kenya border and stretches from Lake Rudolf in the west, eastwards some $\mathbf{5 0 0}$ miles to Dolo and beyond into the Bale-Ogaden territory, including the Provinces of Sidamo-Borana and Gamu-Gofa (but excluding North Sidamo and the Omo River).

Southern Ethiopia can be divided into two main types of country, dry flat scrubland supporting nomadic-owned herds of sheep, camels and horses, and the higher, more mountainous country containing a limited amount of arable land.

On taking up residence at Mega I approached the provincial authoritics rcgarding game and bird licences and, after some delay, I was granted these by the Provincial Director. There was no form and the licence was written in longhand with an Ethiopian seal stamp at the foot of it. When translated from Amharic I found that it informed me of the dates of the close seasons for game, approximating to those of Kenya, and named certain game animals which it was forbidden to shoot. These included elephant, rhino, giraffe, leopard and, surprisingly enough, lion. The maximum number of any animal allowed was not stipulated. It seems that such licences are rarely given, even to their own officials, for some days later, when I showed mine to the Mega Police Commander, he was quite indignant that I had been able to obtain permission when he had none.

On the face of it game protection does exist as ordered by the Central Government in Addis Ababa ; in practice it is enforced, with varying degrees of success, by the administrative and police officials on the spot, who in turn are influenced by the attitude of the Provincial Governor. Animals with a commercial or local value, such as elephant and giraffe, have been largely shot out in the area, though not exterminated. There is no doubt that the present Government inherited a bad legacy in this respect from six years of Italian occupation, followed by the liberation by Commonwealth troops. During that period much wild life was indiscriminately slaughtered. To quote an example: the Italians systematically wiped out the eland in the Jimma and Arussi areas during the occupation, maintaining that the Ethiopian guerillas, who were still fighting on, lived largely off the meat of this animal. To-day the wild animals suffer from the 
depredations of lawless tribesmen of Galla stock armed with rifles. These people are mainly nomadic and live in wild hilly areas difficult of access. As ivory poachers they still cross the frontier and penetrate deep into Kenya, attracted by the lure of "tuskers" on and around Marsabit mountain. The rifles used are mostly old Italian carbines of $\mathbf{2 5 6}$ or $8 \mathrm{~mm}$. calibre, and being inaccurate often wound without being fatal.

The Ethiopian police who patrol the area are allowed to shoot game when on safari if they have no rations, and on the whole they do not appear to abuse this privilege.

There is little variety of gazelle. Impala and Thompson's gazelle do not occur, though I have frequently seen large herds of Grant's gazelle in the many grassy plains of the border country. They carry an unusually pronounced black lateral strike causing the does to look like "Tommies" from a distance, and do not appear unduly timid towards humans. Gerenuk (Waller's gazelle) are plentiful also in the dry bush country. The Beisa oryx, on the other hand, is rarer generally, and has probably been killed off for the sake of its abundant and tasty meat. Recently, however, I saw a large herd of these fine beasts on the Mega-Tertale route, and I estimated that there were over 150 in number. They thundered across the track in our path in a great cloud of dust. Bringing up the rear was an old bull with a single horn; I should like to be able to say that this was growing from the centre of the forehead, but no one would believe me.

Some local tribesmen, copying their Amhara masters, own large herds of horses and go about their travels on horseback. Certain of them hunt illegally by this means and it seems likely that the scarcity of the larger and heavier antelope of the plains can be attributed partly to this factor. In many months of safari I have seen hartebeeste on only two occasions, when they appeared to be Neumann's hartebeeste, but I was unable to approach near enough to be certain.

The giraffe is very scarce in the area and must fall an easy prey to poachers, who prize it for its meat and for its skin, which makes sole leather for their sandals. In startling contrast one sees great numbers of giraffe and oryx in similar terrain a hundred miles to the south, in Kenya territory, where they are extraordinarily approachable. There an adult reticulated giraffe once trod on my car, slightly denting the rear bumper.

The magnificent greater kudu is well distributed in the more hilly regions, though very wary. I have seen groups and small herds in widely separated places, including Mega mountain, 


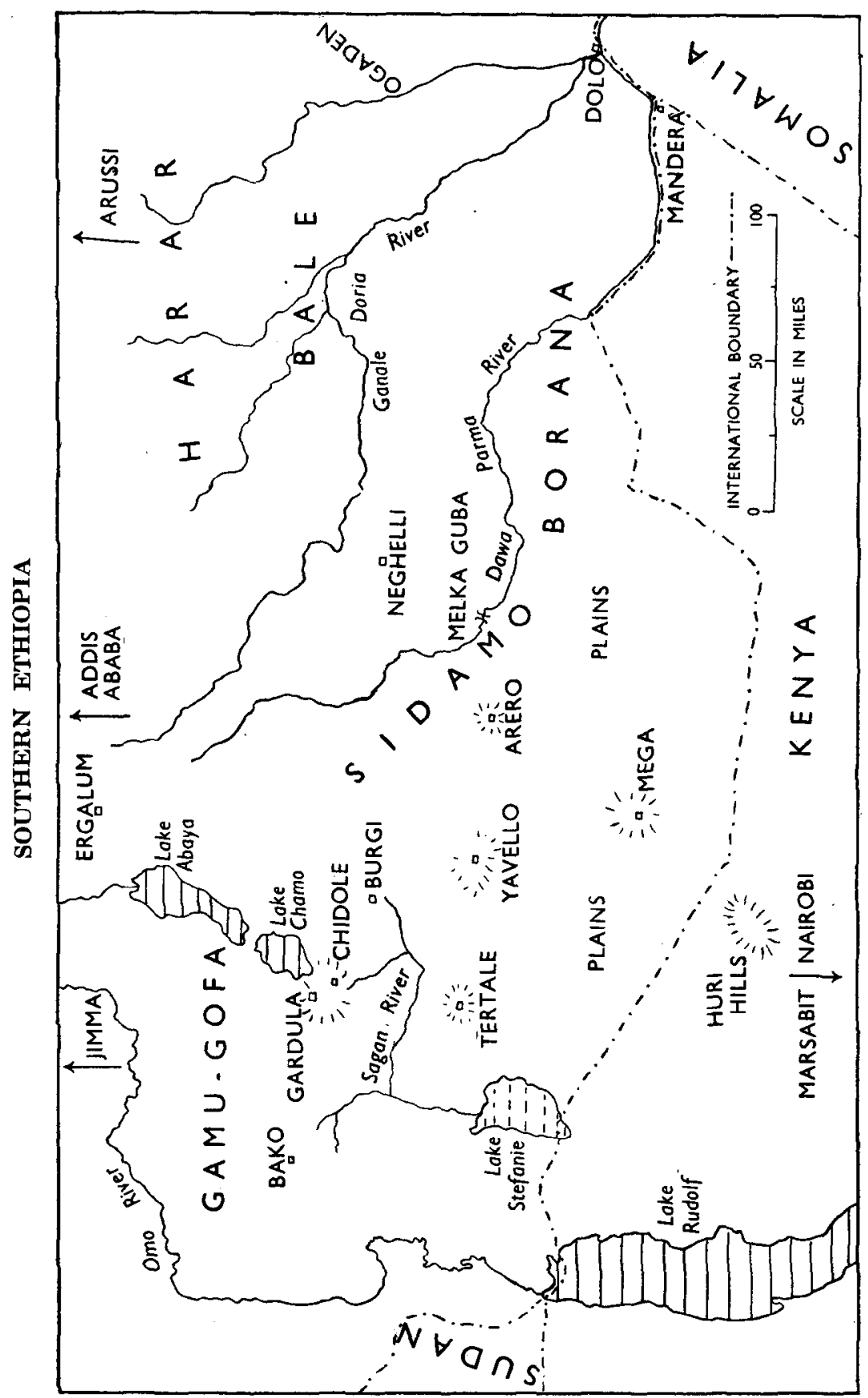


Neghelli District, and the hills around the seasonal Lake Stefanie. As the majority of bulls seen are young, it is unusual to find one whose horns are over 50 inches on the curves, and they are difficult of approach except at dusk. The does, however, are less timid and I have seen them with young, within 400 yards of my house at Mega. It always surprises me that these heavy animals are at home on such incredibly steep hills. In Kenya one can still see herds of these creatures in the desolate, windswept Huri Hills, just south of the border. The lesser kudu is also present, in pairs, in the thicker bush country.

Eland appear to be extinct in the area. The defassa waterbuck is not uncommon in river areas and $I$ have seen herds on the Dawa Parma river from Melka Guba eastwards-also around Lake Chamo. Bushbuck have also been seen fleetingly. The mountain nyala does not reach as far south as this, of course.

Zebra have suffered from indiscriminate hunting and are rare. Grevy's zebra does not appear to exist here; I have seen Burchell's twice only, in small herds, in the hilly country north of Yavello. The rare Somali wild ass may live in the stonier more arid parts, and I saw a pair several years ago near Imi, Central Ogaden.

A friend has told me that he has seen herds of dibatag (Clarke's gazelle) on the Borana-Oddo boundary north-west of Dolo. Unfortunately I have not been able to confirm this report. I believe that this rare gazelle has never been recorded outside the Mudugh province of Somalia and it is to be hoped that the Italian officials there have taken adequate steps to protect it; otherwise the dibatag will soon become extinct.

The smaller antelopes, such as dik-dik and duiker are plentiful. Elephant, however, are now very rare in the area. Only once, near Arero, have I come across fresh elephant spoor, and this showed that the herd was of family dimensions only. Apart from the rugged country behind Arero it is possible that some survive in the Burji-Chamo zone. Rhino are even scarcer and have been poached out for the sake of their valuable horn.

Most of this country is unsuitable for hippo and buffalo except in the Lake Chamo and Lake Abaya areas, where they occur in some numbers. From Chidole, the capital of GamuGofa, 8,000 feet above sea-level, one may look down on Lake Chamo nestling in the hills some 4,000 feet below ; the descent is precipitous. The lake is infested with crocodiles and teems with all sorts of fish, the largest being the giant Nile perch.

Lions are very prevalent throughout. In the hills these creatures seem smaller, with a heavier mane and much darker 
colouring than their brothers of the plain. When camping in the bush one can invariably mark their nocturnal prowling only too clearly, by ear. The leopard is another victim of the poachers, who get a high price for its skin, though it is protected by the Central Government's game laws. Until recently leopards were plentiful on Mega and Gardulla mountains, but are practically wiped out there now. These hill leopards have a thicker and darker coat than others and tend towards melanism; indeed, some are almost black. Sometimes I have seen leopards on stony country, and twice in most arid, waterless lava-desert, where no vegetation could grow. They appeared fat and healthy in spite of it, and I assume that they lived off wandering herds of gazelle, nomadic-owned goats, and perhaps rodents. As there was no water for scores of miles it seems likely that the blood of their victims sufficed. The general dearth of leopards has resulted in a considerable increase in the baboon population. These latter prefer to live high up on the wooded hills, descending into the maize and taf shambas in great numbers to feed and destroy. The black and white Colobus monkey (Colobus abyssinicus) is also suffering from commercialization, and though officially protected is slaughtered in large numbers-witness the numerous colobus rugs which may be purchased to-day in Addis Ababa.

The cheetah is not found in the hills and is rare elsewhere. I have heard several reports from reliable persons, both European and Amhara, that they have seen largish pure black cats in the thicker bush area on several occasions ; I have had no such luck. Unless this is a new species it seems likely that the creature may have been a melanistic servaline or some similar animal.

The southern tribesmen, part-converts to Islam, leave the warthog and bush pig alone, and these flourish on the plains.

The ostrich is fairly plentiful in the scrub-lands, though the eggs are sought after by the Boran, who sell them in the villages ; there seems to be no restriction on this practice. The gaudy vulturine guinea-fowl is common in the frontier belt, with the helmeted guinea-fowl taking its place further inland; an enforced close season preserves these birds. Francolin also are plentiful, with bustard, sandgrouse, and bush partridge in the scrub areas. Egyptian geese are to be found on the Dawa and Ganale rivers, and various species of wild duck on Lake Chamo and the Sagan river.

Abyssinian ground hornbills are common in the valleys, as are hawk-eagles in the hills, the former being protected. The scavengers, both furred and feathered, are prevalent throughiout. 
Looking to the future, it may be said that unless the existing degree of lawlessness in the south can be stamped out, wild life will suffer, and the more vulnerable and commercially valuable creatures may disappear altogether.

\section{THE GOLD COAST \\ REPORT ON THE GAME DEPARTMENT FOR THE YEAR 1950-51}

The Game Department came into being on the 1st April, 1950. Throughout the year work was confined to the Northern Territories of the Gold Coast.

\section{Part I-Game Reserves}

\section{Proposed Black Volta Reserve.}

2. Selection of an area of approximately 600 square miles in Western Gonja was completed. The Selection Report, submitted to His Honour the Chief Commissioner, was discussed by the Central Land Planning Committee at Tamale and approved. The Chief Commissioner recommended to the Ministry of Agriculture and Natural Resources that the proposed reserve be constituted under section 2 (13) of Cap. 203 of the Laws. Consideration of the proposal by the Ministry was delayed because the area impinged upon an area in respect of which a private individual was seeking an exclusive prospecting licence. This application was subsequently withdrawn but the necessary regulation could not be made by the end of the year.

The Kulpawn River Valley.

3. The valley of the River Kulpawn, in Wa District, appeared to be a suitable area for a Game Reserve, but after discussion with the Department of Tsetse Control it was found that a recommendation for resettlement of this area had been made. The project of examining the area of the valley was accordingly abandoned.

\section{Proposed Sisili Game Reserve.}

4. The area of the Sisili Valley, to the north of the TumuNavrongo Road, was examined and was considered suitable as a Game Reserve. The stock of game is better than that in the proposed Black Volta Reserve and includes at least one species, 